\title{
Особливості технічного регулювання щодо медичних інфрачервоних термометрів
}

\section{Р.П. Сергієнко', Ю.Г. Жарко', Р.М. Тріщ²}

'Державне підприємство «Харківський регіональний науково-виробничий центр стандартизації, метрології та сертифікації», Харків, Україна

уУраїнська інженерно-педагогічна академія, Харків, Україна

Анотація. Проведено аналіз розвитку та сучасного стану державного технічного регулювання щодо медичних інфрачервоних термометрів, широке застосування яких обумовлено наразі пандемією COVID-19. Етапи розвитку технічного регулювання умовно віднесено до певних часових періодів - до 2016 р. (1-й етап), 2016-2020рр. (2-й етап) та з 2020 р. по теперішній час (3-й етап). Висвітлено проблемні аспекти стосовно випробувань за процедурами з оцінки відповідності в частині вимог до метрологічних характеристик медичних приладів із функцією вимірювання, щодо термінологічної конкретизації типів медичних термометрів у відповідних нормативних та нормативно-правових документах на кожному з етапів розвитку, щодо стану нормативної бази та відповідних інформаційних ресурсів з точки зору їх доступності для споживачів. Порушено питання періодичного метрологічного контролю медичних інфрачервоних термометрів, які в період пандемії можуть надаватися на ринку за процедурами, альтернативними вимогам Технічного регламенту щодо медичних виробів.

Ключові слова: медичні вироби, медичні інфрачервоні термометри, випробування, технічний регламент, законодавчо регульовані засоби вимірювальної техніки, оцінка відповідності.

\section{Вступ}

Вимірювання температури тіла людини $\epsilon$ необхідною та важливою процедурою у медичній практиці, оскільки його результат дозволяє контролювати стан пацієнта та перебіг хвороби, встановлювати або уточнювати діагноз та застосовувати відповідні протоколи лікування. Термометри для вимірювання температури тіла - найпоширеніші медичні прилади, якими споживачі користуються у побуті. Класичними зразками таких приладів $\epsilon$ контактні засоби вимірювання температури, до яких, перш за все, належать скляні ртутні термометри, які в певний період були єдиними приладами для вимірювання температури людського тіла. 3 появою високоточних термісторів як датчиків температури у практику увійшли електронні медичні термометри. Істотними недоліками зазначених контактних засобів $\epsilon$ небезпека й екологічні ризики при використанні ртуті та тривалість процедури вимірювання внаслідок необхідності досягнення теплової рівноваги з певними ділянками тіла людини.

У 1990-х роках на світовому ринку з'явилися перші медичні вушні інфрачервоні термометри. Преференціями цих засобів $\epsilon$ гігієнічність через відсутність механічного контакту з тілом людини та швидкість визначення температури. Саме застосування безконтактних засобів вимірювання температури у місцях масового скупчення людей (аеропорти, морські порти тощо) сприяло зниженню ризику поширення тяжкого гострого респіраторного синдрому, викликаного коронавірусом SARS-CoV, у 2002-2004 рр. Серйозним викликом сучасності $\epsilon$ пандемія COVID-19, внаслідок чого невід'ємною рисою повсякденного життя став контроль температури тіла людей, в тому числі й поза межами медичних закладів. 3 весни 2020 р. практично перед кожним суб'єктом господарювання незалежно від форми власності та виду діяльності постало завдання моніторингу температури тіла людей, якими можуть бути працівники підприємств, відвідувачі закладів, учасники масових заходів, пересічні громадяни або туристи. Таким чином, затребуваність приладів для безконтактного вимірювання температури людського тіла зросла на порядки, про що, зокрема, свідчить доступна в інтернеті інформація щодо закупівель медичних інфрачервоних термометрів (MIT). При цьому варто зазначити, що МIT, які надходять на ринок України, зазвичай зарубіжного виробництва i за конструкцією їх можна умовно поділити на три групи: вушні термометри (ear thermometers, tympanic thermometers), лобні термометри (forehead thermometers) та термометри пістолетного типу, які здебільшого застосовують для вимірювання температури шкіри людини (рис. 1). При цьому в деяких моделях термометрів може бути комбінація $\geq 2$ режимів роботи.
Рисунок 1 Приклади MIT: a - «GentleTemp 520» (вушний), b «GentleTemp 720» (лобний), с — «DT-8806Н» (пістолетного типу), d — «Dr. Frei Ml-100» (функції вушного і лобного)

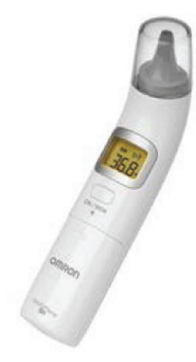

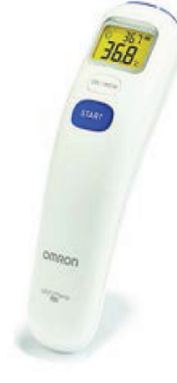

b

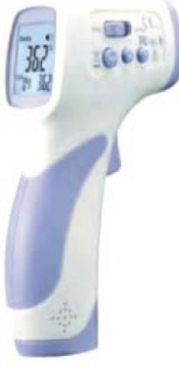

C

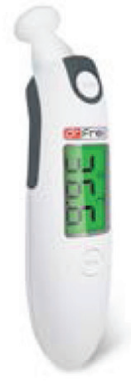

d
Як свідчить практика, у представників бізнесу та споживачів як на етапі закупівлі, так і в процесі експлуатації виникають питання щодо регуляторної політики, яка впроваджується стосовно вищезазначених приладів. Зважаючи на актуальність проблеми, метою роботи $\epsilon$ аналіз розвитку та сучасного стану технічного регулювання, в тому числі нормативної бази щодо MIT. Висвітлення деяких аспектів у цій сфері може бути підставою для обговорення серед фахівців 3 питань законодавчої метрології, оцінки відповідності, метрологів калібрувальних лабораторій та медичних працівників, а також сприятиме формуванню системного підходу стосовно питань з оцінки відповідності MIT, проведення робіт з контролю метрологічних характеристик під час експлуатації, а також стосовно напрямів актуалізації та розроблення нормативних та нормативно-правових документів.

\section{Етапи розвитку державного \\ технічного регулювання}

Етапи розвитку державного технічного регулювання стосовно МІТ умовно можна віднести до певних часових періодів - до 2016 р. (1-й етап), 2016-2020рр. (2-й етап) та з 2020 р. по теперішній час (3-й етап) з необхідними перехідними інтервалами між ними, протягом яких діяли або діють відповідні регламентуючі документи та усталена практика потрапляння на ринок країни зазначених приладів з подальшим періодичним контролем їх метрологічних характеристик (табл. 1).

Відповідно до термінології [1] МІТ відносять до засобів вимірювальної техніки (ЗВТ) медичного призначення (рис. 2). 
Таблиця 1 Основні регламентуючі документи відповідно до етапів розвитку технічного регулювання МIT

\begin{tabular}{cl}
\hline Eтап & \multicolumn{1}{c}{ Основні регламентуючі документи } \\
\hline 1-й & ДСТу 3400:2006 Метрологія. Державні випробування засобів вимірювальної \\
& техніки. Основні положення, організація, порядок проведення і розгляду \\
& результатів (скасований 29.03.2017 р.) \\
& ДСТу 3627:2005 Вироби медичні. Розроблення і ставлення на виробництво. \\
& Основні положення \\
\hline 2-й & Постанова Кабінету Міністрів України від 13.01.2016 р. № 94 «Про затвердження \\
& Технічного регламенту законодавчо регульованих засобів вимірювальної техніки» \\
& Постанова Кабінету Міністрів України від 04.06.2015 р. № 374 «Про затвердження \\
& переліку категорій законодавчо регульованих засобів вимірювальної техніки, що \\
& підлягають періодичній повірці» \\
\hline 3-й & Постанова Кабінету Міністрів України від 02.10.2013 р. № 753 «Про затвердження \\
& Технічного регламенту щодо медичних виробів» \\
& Постанова Кабінету Міністрів України від 10.07.2019р. № 598 «Про внесення змін \\
& до Технічного регламенту законодавчо регуль0ванихзасобів вимірювальної техніки» \\
\hline
\end{tabular}

Рисунок 2 Термінологія відповідно до ДСТУ 3627 [1]

\begin{tabular}{|c|c|}
\hline \multicolumn{2}{|c|}{ Вироби медичні } \\
\hline$\downarrow$ & $\downarrow$ \\
\hline Вироби медичної техніки & Вироби медичного призначення \\
\hline$\downarrow$ & \\
\hline उBT & аачення \\
\hline
\end{tabular}

\section{1-й етап}

До січня 2016 р. на ЗВТ, які підлягали ввезенню на територію України партіями, поширювалася процедура державних випробувань, регламентована чинним на той час нормативним документом ДСТУ 3400 . До основних завдань державних випробувань належали встановлення відповідності ЗВТ вимогам нормативних документів та технічній документації іноземного виробника; перевірка правильності вибору методу і засобів повірки (калібрування) 3ВТ, а також забезпечення ЗВТ методиками повірки (калібрування) та робочими еталонами під час випуску з виробництва, після ремонту та експлуатації; перевірка відповідності ЗВТ вимогам безпеки та охорони довкілля.

На відміну від промислових інфрачервоних термометрів (пірометрів, перетворювачів пірометричних), для яких було стандартизовано термінологію, основні технічні вимоги та методи випробувань [2-4], для МIT такі нормативні документи були відсутні. Випробування MIT зазвичай проводили аналогічно до випробувань промислових пірометрів. Комплекс досліджень під час випробувань охоплював технічні та метрологічні характеристики пірометрів, зокрема такі, як діапазон вимірювань, межі допустимої основної похибки та значення додаткової похибки, обумовленої зміною впливних величин, а також міг доповнюватися операціями $з$ урахуванням ДСТУ 3627 [1], наприклад, стосовно стійкості до стерилізації та дезінфікування насадок для вушних MIT.

Важливо зазначити, що згідно з ДСТУ 3627 [1] задовільні результати державних приймальних випробувань були підставою для направлення зразків медичних виробів, принаймні призначених для виробництва в Україні, на клінічні випробування. Необхідність клінічних випробувань (клінічних досліджень) $€$ однією 3 ключових відмінностей між процедурами випробувань медичних та немедичних (промислових) інфрачервоних термометрів. Мета клінічних досліджень полягає в оцінюванні ефективності та безпеки медичного виробу під час експлуатації, а одним із завдань проведення клінічного випробування $\epsilon$ виявлення відповідності медичного виробу його клінічному призначенню [1]. Результати клінічних досліджень МІT зарубіжного виробництва могли надаватися компанією-виробником у вигляді протоколів попередніх випробувань у комплекті з методикою клінічних досліджень. Оцінка достатності обсягу та методичної правильності таких випробувань зазвичай визначалася виконавцями - фахівцями в галузі метрології, які могли не мати певного або достатнього досвіду у сфері поводження із ЗВТ медичного призначення та процедурами проведення та обробки результатів клінічних досліджень.
За результатами державних приймальних випробувань складали опис типу 3ВТ, який вносили до Державного реєстру 3ВТ [5] із відповідним реєстраційним номером, у формі запису якого фіксували рік складання (або перегляду за результатами державних контрольних випробувань) опису типу. В табл. 2 наведено інформацію щодо MIT у зазначеному реєстрі, який наразі має інформативний характер. Як можна бачити, наявні три позиції, дві з яких внесено до реєстру у 2015 р. Враховуючи періодичність проведення випробувань (3 роки), строк дії сертифікатів затвердження типів ЗВТ (у разі проведення державних приймальних випробувань) або сертифікатів відповідності ЗВТ затвердженому типу (у разі проведення державних контрольних випробувань) міг тривати до 28.12.2018 р. В усіх назвах ЗВТ є прикметник «медичні», але відсутня ідентифікація приладів за конструкцією, тобто до якого типу вони належать (вушні, лобні тощо).

Таблиця 2 Відомостіз Державного реєстру 3ВТ станом на 31.12.2015 p. щодо MIT [5]

\begin{tabular}{|c|c|c|c|}
\hline Назва 3ВТ & $\begin{array}{c}\text { Умовне } \\
\text { позначення 3ВТ }\end{array}$ & Виробник & $\begin{array}{l}\text { Реєстраційний } \\
\text { номер }\end{array}$ \\
\hline $\begin{array}{l}\text { Термометри } \\
\text { інфрачервоні медичні }\end{array}$ & DT... & $\begin{array}{l}\text { «Shenzhen Everbest Machinery } \\
\text { Industry Co.», Ltd, KHP }\end{array}$ & У3443-13 \\
\hline $\begin{array}{l}\text { Термометри медичні } \\
\text { інфрачервоні }\end{array}$ & GentleTemp... & $\begin{array}{l}\text { «OMRON Healthcare Co. Ltd», } \\
\text { Японія }\end{array}$ & У1657-15 \\
\hline $\begin{array}{l}\text { Термометри медичні } \\
\text { електронні } \\
\text { інфрачервоні }\end{array}$ & Dr. Frei MI... & $\begin{array}{l}\text { «ForaCare Suisse AG», } \\
\text { Швейцарія, на заводі фірми } \\
\text { «Biocare Asia Corporation», KНP }\end{array}$ & У3613-15 \\
\hline
\end{tabular}

Інформацію щодо забезпечення методиками повірки та робочими еталонами після ремонту та під час експлуатації вказували у відповідному розділі опису типу. За відсутності національного нормативного документа на методику повірки відповідну методику розробляли під час випробувань для конкретних типів МIT або наводили в описі типу посилання на певний розділ експлуатаційного документа.

\section{2-й етап}

Наступний етап розвитку технічного регулювання щодо MIT характеризується прийняттям нормативно-правових актів, спрямованих на узгодження та гармонізацію національного законодавства з відповідними документами Європейського Союзу.

Постановою Кабінету Міністрів України (КМУ) від 04.06.2015 р. № 374 [6] визначено категорії 3ВТ, які належать до законодавчо регульованих. Відповідно до зазначеної постанови МIT належать до п. 45 переліку категорій — «медичні термометри», які підлягають періодичній повірці у разі застосування їх у сфері законодавчо регульованої метрології, а саме для забезпечення захисту життя та охорони здоров'я громадян [7].У такому записі- «медичні термометри»відсутня конкретизація щодо видів медичних термометрів - скляні ртутні, електронні цифрові або інфрачервоні. За даними [8], в Європі $\epsilon$ країни, де аналогічні позиції («clinical thermometers») або конкретні моделі термометрів, наприклад «clinical electric thermometers», входять до сфери законодавчо регульованої метрології. Зазначимо, що у світі також $є$ країни, де медичні термометри, зокрема інфрачервоні, не $\epsilon$ предметом регулювання в рамках законодавчої метрології.

Постановою КМУ від 13.01.2016 р. № 94 затверджено Технічний регламент (ТР) законодавчо регульованих засобів вимірювальної техніки [9], який набув чинності 04.09.2016 р. та на момент прийняття встановлював вимоги й до медичних термометрів (п. 44 Додатку 1). Таким чином, для надання на ринку або введення в експлуатацію медичних термометрів, зокрема MIT, вони підлягали оцінці відповідності вимогам [9]. Суттєві вимоги, яким повинні відповідати ЗВТ, викладено у зазначеному ТР і вони охоплюють такі характеристики та властивості 3ВТ:

- допустима похибка за нормованих робочих умов і за відсутності перешкод (впливних величин);

- експлуатаційні характеристики за нормованих робочих умов і за наявності відповідної перешкоди. При цьому випробування проводяться для кожної відповідної величини, яка впливає на точність ЗВТ (кліматичні умови навколишнього середовища, зовнішні механічні та електромагнітні умови тощо); 
- відтворюваність, повторюваність, поріг реагування і чутливість, довговічність, надійність, придатність;

- конструкція ЗВТ, застосоване програмне забезпечення та захист від несанкціонованого втручання.

Отже, суттєвими вимогами повною мірою охоплюються метрологічні та технічні характеристики ЗВТ і, з точки зору метрології, випробування щодо зазначених характеристик $є$ достатніми для визначення відповідності ЗВТ. Як зазначено вище, специфічність випробувань ЗВТ медичного призначення обумовлюється необхідністю проведення клінічних випробувань, які власне у суттєвих вимогах [9] не зазначаються. Проте окрім [9], на вказані 3ВТ може поширюватися дія ТР щодо медичних виробів [10], аналіз вимог якого проводиться далі.

TP [9] містить посилання на перелік стандартів, добровільне застосування яких $є$ доказовою базою відповідності ЗВТ встановленим вимогам. За період з січня 2016 до грудня 2019 р. перелік національних стандартів, відповідність яким надавала презумпцію відповідності ЗВТ суттєвим вимогам ТР законодавчо регульованих 3ВТ, тричі редагувався та затверджувався наказами Міністерства економічного розвитку і торгівлі України. У табл. 3 наведено позиції із зазначених переліків для застосовуваних національних стандартів щодо медичних термометрів. Так, жодного нормативного документа стосовно МIT в редакціях переліків стандартів не було, а в переліку доказової бази, затвердженому у 2018 р., взагалі відсутні стандарти щодо медичних термометрів.

Таблиця 3 Інформація з переліків національних стандартів, відповідність яким надавала презумпцію відповідності медичних термометрів суттєвим вимогам ТР законодавчо регульованих ЗВТ

\begin{tabular}{clc}
\hline $\begin{array}{c}\text { Позначення } \\
\text { національного } \\
\text { стандарту }\end{array}$ & \multicolumn{1}{c}{$\begin{array}{c}\text { Назва } \\
\text { національного стандарту }\end{array}$} & $\begin{array}{c}\text { Дата початку надання } \\
\text { презумпції відповідності } \\
\text { внаслідок застосування } \\
\text { національного стандарту }\end{array}$ \\
\hline Наказ Міністерства економічного розвитку і торгівлі України від 01.09.2016 p. \\
№ 1435
\end{tabular}

Наказ Міністерства економічного розвитку і торгівлі України від 05.05.2018 p.

№ 622

Наказ Міністерства економічного розвитку і торгівлі України від 23.04.2019 р. № 717

\begin{tabular}{llc}
\hline $\begin{array}{l}\text { ДСТУ 0IML R 7:2018 } \\
\text { (OIML R 7:1979, IDT) }\end{array}$ & $\begin{array}{l}\text { Термометри медичні максимальні } \\
\text { ртутні скляні }\end{array}$ & $23.04 .2019 \mathrm{p}$. \\
\hline ДСТУ 0IML R 114:2018 & Термометри медичні електричні & $23.04 .2019 \mathrm{p}$. \\
(OIML R 114:1995, IDT) & для безперервного вимірювання & \\
\hline ДСТУ 0IML R 115:2018 & Термометри медичні максимальні & $23.04 .2019 \mathrm{p}$. \\
(OIML R 115:1995, IDT) & електричні & \\
\hline ДСТУ 0IML R 133:2018 & Термометри типу рідина-у-склі & $23.04 .2019 \mathrm{p}$. \\
(OIML R 133:2002, IDT) & &
\end{tabular}

Оцінку відповідності для ЗВТ медичного призначення проводили за визначеними уніфікованими процедурами - модулями або їх комбінаціями. Так, для оцінки відповідності медичних термометрів застосовували комбінації модулів «B+D» aбо «B+F». За результатами перевірки типу MIT за модулем «В» видавали сертифікат перевірки типу, а ЗВТ заносили до Реєстру затверджених типів ЗВТ [5] (табл. 4). Станом на 19.01.2020 р. до зазначеного реєстру внесено три позиції для МIT, серед яких термометри різних конструкцій, зокрема вушні (наприклад MDI-901) та пістолетного типу (MDI-907).

Таким чином, для споживачів є доступною інформація щодо типів MIT, які проходили оцінку відповідності принаймні у період з січня 2016 до січня 2020 р., та, відповідно, щодо строків дії сертифікатів перевірки типу. Як можна бачити, у назвах типів ЗВТ не вживається прикметник «медичні», що за формальною ознакою не відповідає
Таблиця 4 Інформація з Реєстру затверджених типів ЗВТ станом на 19.01.2020 р. [5] щодо МІТ, стосовно яких виконано процедуру з оцінки відповідності за модулем «В»

\begin{tabular}{|c|c|c|c|c|}
\hline Тип 3ВТ & $\begin{array}{c}\text { Умовне } \\
\text { позначення } \\
\text { типу ЗВТ }\end{array}$ & $\begin{array}{c}\text { Найменування } \\
\text { та місцезнаходження } \\
\text { виробника ЗВТ }\end{array}$ & $\begin{array}{c}\text { Дата видачі } \\
\text { сертифіката } \\
\text { перевірки } \\
\text { типу }\end{array}$ & $\begin{array}{c}\text { Строк дії } \\
\text { сертифіката } \\
\text { перевірки } \\
\text { типу }\end{array}$ \\
\hline $\begin{array}{l}\text { Термометри } \\
\text { електронні } \\
\text { інфрачервоні }\end{array}$ & IT-, DT- & «A\&D Company», Японія & 29.03.2019p. & 29.03.2029p. \\
\hline $\begin{array}{l}\text { Термометри } \\
\text { безконтактні } \\
\text { інфрачервоні }\end{array}$ & $\begin{array}{l}\text { MDI901, } \\
\text { MDI907 }\end{array}$ & $\begin{array}{l}\text { «ShenZhen Medek } \\
\text { Bio-Medical Co.», KHP }\end{array}$ & 05.03.2019p. & 05.03.2029p. \\
\hline $\begin{array}{l}\text { Інфрачервоний } \\
\text { термометр }\end{array}$ & HTD8808E & $\begin{array}{l}\text { «Contec Medical } \\
\text { Systems Co.», KHP }\end{array}$ & 28.09.2018p. & 28.09.2028p. \\
\hline
\end{tabular}

п. 45 документа $[6,11]$. Варто зауважити, що до переліку категорій [6] також входять «термометри» за п. 74, до яких, на перший погляд, можна віднести й інфрачервоні термометри промислового призначення, які на практиці можуть використовуватись у таких сферах законодавчо регульованої метрології, як контроль якості та безпеки харчових продуктів і лікарських засобів, контроль безпеки умов праці, роботи, що виконуються за дорученням органів досудового розслідування, органів прокуратури та судів [7]. Але така практична можливість наразі не узгоджується з [11], де прикметник «інфрачервоні» $є$ відсутнім у розділі «термометри» та, до речі, й у розділі «медичні термометри». Таким чином, за потреби фахівцю треба проявити в певному сенсі винахідливість, щоб віднести, наприклад, вушні інфрачервоні термометри згідно з пунктом «45» у [11] до «термометрів медичних цифрових», а інфрачервоні термометри промислового призначення, згідно з пунктом «74» у [11], - до «термометрів цифрових» або «приладів багатофункціональних з каналом вимірювання температури».

Для контролю метрологічних характеристик ЗВТ у процесі їх експлуатації впроваджено Порядок проведення повірки законодавчо регульованих засобів вимірювальної техніки, що перебувають в експлуатації, та оформлення її результатів [12]. Міжповірочні інтервали за категоріями законодавчо регульованих 3ВТ встановлено відповідно до [13]. При цьому, на відміну від [6], де визначенням «медичні термометри» охоплюються всі види термометрів, в документі [13] міститься певна класифікація термометрів (цифрові, скляні з органічним заповненням, скляні ртутні), яка корелює з міжповірочними інтервалами. За відсутності чіткості формулювань можна припустити, що МІT розглядають як цифрові термометри, але, щиро кажучи, це не є очевидним фактом.

3 метою забезпечення національними нормативними документами на методики повірки законодавчо регульованих ЗВТ Міністерством економічного розвитку і торгівлі України вживалися заходи щодо розробки проєктів зазначених методик. Зокрема, розроблено проєкт методики на повірку МIT [14], сфера застосування якої поширюється на вушні MIT.

\section{3-й етап}

Постановою КМУ від 10.07.2019 р. № 598 [15], яка набула чинності з 19.01.2020 р., внесено зміни до ТР законодавчо регульованих ЗВТ, відповідно до яких ЗВТ медичного призначення, в тому числі медичні термометри, виводяться 3-під регуляторної дії ТР законодавчо регульованих ЗВТ. 3 19.01.2020 р. на зазначені ЗВТ поширюється дія лише ТР щодо медичних виробів [10], проте вони залишаються законодавчо регульованими ЗВТ та відповідно до [6] підлягають періодичній повірці з дотриманням встановлених міжповірочних інтервалів. Як зазначено у Пояснювальній записці до відповідного проєкту Постанови КМУ [16], головна мета змін — «усунення подвійної оцінки відповідності» медичних виробів з функцією вимірювання вимогам TP $[9,10]$.

У [10] визначено поняття «медичні вироби» та формується нова термінологія стосовно ЗВТ медичного призначення - медичні вироби з функцією вимірювання. Згідно з термінологічними визначеннями, наведеними у додатку 2 до ТP [10], МІT можна віднести до «активного медичного виробу», оскільки його робота залежить від джерела електричної енергії, або до «активного медичного виробу для діагностики», яким є будь-який активний медичний виріб, 
Таблиця 5 Інформація з переліку національних стандартів, відповідність яким надає презумпцію відповідності медичних термометрів вимогам ТР щодо медичних виробів [18]

\begin{tabular}{|c|c|c|c|}
\hline $\begin{array}{c}\text { Позначення } \\
\text { національного } \\
\text { стандарту }\end{array}$ & Назва національного стандарту & $\begin{array}{c}\text { Позначення } \\
\text { гармонізованого } \\
\text { європейського } \\
\text { стандарту }\end{array}$ & $\begin{array}{c}\text { Дата першого } \\
\text { опублікування } \\
\text { гармонізованого } \\
\text { європейського стандарту } \\
\text { в 0фіційному віснику ЄС }\end{array}$ \\
\hline ДСТУ ЕN 12470-1:2014 & Медичні термометри. Частина 1. Скляні максимальні термометри & EN 12470-1:2000+A1:2009 & 02.12 .2009 \\
\hline ДСТУ ЕN 12470-2:2014 & Медичні термометри. Частина 2. Термометри фазового переходу (точкова матриця) & EN 12470-2:2000+A1:2009 & 02.12 .2009 \\
\hline $\begin{array}{l}\text { ДСТУ ЕN 12470-3:2019 } \\
\text { (чинний д0 01.01.2020) }\end{array}$ & $\begin{array}{l}\text { Медичні термометри. Частина 3. Робочі характеристики компактних електричних термометрів } \\
\text { (непрогнозовані та прогнозовані) з максимальною межею вимірювання пристрою }\end{array}$ & EN 12470-3:2000+A1:2009 & 02.12 .2009 \\
\hline ДСТУ ЕN 12470-4:2019 & $\begin{array}{l}\text { Медичні термометри. Частина 4. Робочі характеристики електричних термометрів для безперервного } \\
\text { вимірювання }\end{array}$ & EN 12470-4:2000+A1:2009 & 02.12 .2009 \\
\hline ДСТУ ЕN 12470-5:2019 & $\begin{array}{l}\text { Медичні термометри. Частина 5. Робочі характеристики інфрачервоних термометрів для вуха } \\
\text { (з максимальною межею вимірювання пристрою) }\end{array}$ & EN 12470-5:2003 & 07.11 .2003 \\
\hline
\end{tabular}

що використовують окремо або у поєднанні з іншими медичними виробами з метою одержання інформації для виявлення, діагностики, моніторингу фізіологічних умов та стану здоров'я людини. У [10] наведено класифікацію медичних виробів за класами I, Ila, II6 і III згідно з цільовим призначенням. Саме з класом медичного виробу пов'язаний вибір процедур з оцінки відповідності. За критеріями, що пропонуються в [10], MIT можна віднести до класу I як неінвазивні медичні вироби та до класу lla як активні медичні вироби, призначені для прямого діагностування або моніторингу життєво важливих фізіологічних процесів. Для оцінки відповідності медичних виробів з функцією вимірювання класів I та Іlа застосовують процедури, наведені у додатках 5-8 ТР [17].

У додатку 1 до ТР [10] викладено основні вимоги до медичних виробів, в тому числі до медичних виробів із функцією вимірювання. Для останніх зазначено, що вони повинні бути розроблені і виготовлені таким чином, щоб забезпечити точність вимірювання у встановлених межах точності з урахуванням їх призначення. Для метролога $\epsilon$ закономірним питання, про яку власне метрологічну характеристику йдеться, можливо, про межі допустимої похибки за нормованих робочих умов. Як можна бачити, в [10] не формулюються вимоги до інших метрологічних характеристик, зокрема й до характеристик точності за умови впливних величин. Власне порівняння вимог до законодавчо регульованих ЗВТ — медичних виробів із функцією вимірювання, викладених в ТР [9, 10], свідчить про відсутність дублювання вимог щодо метрологічних характеристик у двох зазначених ТР. Варто зауважити, що у ТР [10] (додаток 10) зазначається про необхідність клінічних досліджень медичних виробів, які повинні проводитися відповідно до Гельсінської декларації, ухваленої 18-ю Всесвітньою медичною асамблеєю.

Згідно з [18] встановлено перелік національних стандартів, відповідність яким надає презумпцію відповідності медичних виробів вимогам ТР щодо медичних виробів. В табл. 5 наведено позиції із зазначеного переліку, які стосуються медичних термометрів. Як можна бачити, до МІТ відноситься один стандарт, який, зважаючи на назву, стосується лише вушних MIT.

У період 2010-2015 рр. згідно з Порядком державної реєстрації медичної техніки та виробів медичного призначення [19], чинним на той час, до Державного реєстру медичної техніки та виробів медичного призначення [20] було внесено 34 позиції медичних термометрів, 3 яких 16 відповідно до назв виробів стосуються ци $\phi-$ рових (електронних) термометрів, 9-медичних скляних термометрів, як ртутних, так і без вмісту ртуті. Деякі позиції мають достатньо узагальнювальну назву, як «термометри медичні» або «термометри клінічні». У табл. 6 наведено інформацію із зазначеного реєстру щодо медичних вушних термометрів, при цьому у назві виробу відсутній термін «інфрачервоні». Шляхом порівняння з табл. 2 споживач може припустити, що йдеться саме про безконтактні вушні медичні термометри певного виробника.

Видається логічним, що доступність та прозорість інформації про результати робіт з оцінки відповідності медичних виробів, в тому числі з функцією вимірювання, має забезпечуватися внесенням таких виробів до аналогічного реєстру. Проте через втрату чинності Постанови № 1497, відповідно до якої визначався механізм формування Державного реєстру медичної техніки та виробів медичного призначення [19], з 01.07.2015 р. актуалізація зазначеного реєстру не проводилася. Також проблематичним $\epsilon$ пошук інформації щодо тих медичних виробів, які вводяться в обіг на території країни за процедурами, відмінними від викладених у ТР щодо медичних виробів. Так, згідно з [10] за певних обставин альтернативним заходом для введення в обіг та/або експлуатацію медичних виробів $\epsilon$ визнання призначеним органом з оцінки відповідності результатів оцінки відповідності, проведеної зарубіжними акредитованими органами з оцінки відповідності.

Варто зазначити, що МІT як медичні вироби для скринінгу хворих входять до переліку товарів, що $€$ необхідними для запобігання поширенню COVID-19 [21]. Надання на ринку таких медичних виробів дозволяється також на підставі «повідомлення Міністерства охорони здоров'я» [10] про «введення в обіг та/або експлуатацію окремих медичних виробів, стосовно яких не виконані вимоги ТР, але використання яких необхідне в інтересах охорони здоров'я». Наявність такого повідомлення, очевидно, має бути підставою для подальшого метрологічного контролю (повірки) медичного виробу як законодавчо регульованого 3ВТ.

\section{ВисновкИ}

У роботі проведено аналіз етапів розвитку та сучасного стану державного технічного регулювання щодо MIT, широке застосування яких обумовлюється наразі пандемією COVID-19. Висвітлено певні проблемні аспекти у цій сфері, зокрема при розгляді випробувань за процедурами з оцінки відповідності в частині вимог до метрологічних характеристик, стану нормативної бази, забезпечення методиками повірки МIT як законодавчо регульованих 3ВТ, стану відповідних інформаційних ресурсів з точки зору їх доступності для фахівців та пересічних споживачів.

Термінологія документів $[6,11,13]$ не передбачає конкретизації такого типу медичних термометрів, як «інфрачервоні» або «безконтактні». На сьогодні з декількох типів МІT вимоги стандартизовано лише стосовно вушних термометрів.

Порівняння суттєвих вимог ТР законодавчо регульованих ЗВТ та основних вимог ТР щодо медичних виробів свідчить про відсутність дублювання вимог цих ТР в частині метрологічних характеристик медичних виробів із функцією вимірювання. Становить інтерес порівняння вимог стандарту ДСТУ EN 12470-5 (табл. 6) до технічних і метрологічних характеристик та до відповідних випробувань і клінічних оцінювань з аналогічними вимогами вищезазначених ТР, а також аналіз підходів у метрологічній практиці та процедурах з оцінки відповідності стосовно інших типів МIT, зокрема пістолетного типу для вимірювання температури шкіри людини, що може бути предметом подальших досліджень.

Таблиця 6 Інформація з Державного реєстру медичної техніки та виробів медичного призначення станом на 01.07.2015 р. [20] щодо медичних вушних термометрів

\begin{tabular}{|c|c|c|c|c|c|}
\hline $\begin{array}{c}\text { № } \\
\text { свідоцтва }\end{array}$ & Назва виробу & Назва виробника & $\begin{array}{c}\text { Країна } \\
\text { виробника }\end{array}$ & $\begin{array}{c}\text { Дата } \\
\text { наказу }\end{array}$ & $\begin{array}{l}\text { Номер } \\
\text { наказу }\end{array}$ \\
\hline $4131 / 2014$ & $\begin{array}{l}\text { Термометри вушні } \\
\text { електронні «OMRON» }\end{array}$ & $\begin{array}{l}\text { «OMRON HEALTHCARE } \\
\text { Co.», Ltd. (Японія) }\end{array}$ & $\begin{array}{l}\text { Китай, } \\
\text { Японія }\end{array}$ & 27.06.2014p. & 823 \\
\hline
\end{tabular}


Порушено питання періодичного метрологічного контролю MIT, які в період пандемії можуть надаватися на ринку за процедурами, альтернативними вимогам ТР щодо медичних виробів.

\section{Конфлікт інтересів}

Автори заявляють про відсутність фінансових або інших конфліктів з приводу написання, підготовки та публікації статті.

\section{Список використаної літератури/References:}

1. ДСТУ 3627:2005. Вироби медичні. Розроблення і ставлення на виробництво. Основні положення (online.budstandart.com/ua/catalog/doc-page.html?id_doc=67067).

2. ДСТУ3518-97. Термометрія. Терміни та визначення (budstandart.ua/normativ-document. html?id_doc=82996\&minregion=852).

3. ДСТУ 3170-95. Пірометри. Загальні технічні вимоги (online.budstandart.com/ua/catalog/ doc-page.html?id_doc=92025).

4. ДСТУ 3765-98. Пірометри. Методи випробувань (online.budstandart.com/ua/catalog/ doc-page.html?id_doc=82384).

5. www.ukrcsm.kiev.ua/index.php/en/services-ua/metrology-ua/regestry-metrology-ua

6. МУ (2015) Постанова КМУ від 04.06.2015 р. № 374 «Про затвердження переліку категорій законодавчо регульованих засобів вимірювальної техніки, що підлягають періодичній повірці» (zakon.rada.gov.ua/laws/show/374-2015-\%D0\%BF\#n9).

7. Верховна Рада України (2014) Закон України № 1314-VII «Про метрологію та метрологічну діяльність» (zakon.rada.gov.ua/laws/show/1314-18\#Text).

8. www.welmec.org/legal-metrology-information/country-information/

9. КМУ (2016) Постанова КмУ від 13.01.2016 p. № 94 «Про затвердження Технічного регламенту законодавчо регульованих засобів вимірювальної техніки» (zakon.rada.gov.ua/ laws/show/94-2016-\%D0\%BF\#n10).

10. КМУ (2013) Постанова КМУ від 02.10.2013 р. №753 «Прозатвердження Технічного регламенту щодо медичних виробів» (zakon.rada.gov.ua/laws/show/753-2013-\%D0\%BF\#Text).

11. Міністерство економічного розвитку і торгівлі України (2015) Наказ Міністерства економічного розвитку і торгівлі України від 21.12.2015 р. № 1719 «Про затвердження Норм часу, необхідного для проведення повірки законодавчо регульованих засобів вимірювальної техніки, що перебувають вексплуатації) (https://zakon.rada.gov.ua/laws/show/Z0051-16\#Text).

12. Міністерство економічного розвитку і торгівлі України (2016) Наказ Міністерства економічного розвитку і торгівлі України від 08.02.2016 p. № 193 «Про затвердження Порядку проведення повірки законодавчо регульованих засобів вимірювальної техніки, що перебувають в експлуатації, та оформленняіїрезультатів» (zakon.rada.gov.ua/laws/ show/z0278-16\#Text).

13. Міністерство економічного розвитку і торгівлі України (2016) Наказ Міністерства економічного розвиткуіторгівліУкраїни від 13.10.2016р. № 1747 «Прозатвердження міжповірочних інтервалів законодавчо регульованих засобів вимірювальної техніки, що перебувають в експлуатації, за категоріями» (zakon.rada.gov.ua/laws/show/z1417-16\#Text).

14. www.metrology.kharkov.ua/fileadmin/user_upload/data_sc/sc4/download/DSTU_IS0/187/ DSTU_Medichni_infrachervoni_cifrovi_proekt2_korr_vushni_13_10_2017.doc

15. кмУ (2019) Постанова КМУ від 10.07.2019 р. № 598 «Про внесення змін до Технічного регламенту законодавчо регульованих засобів вимірювальної техніки» (zakon.rada. gov.ua/laws/show/598-2019-\%D0\%BF\#n11).

16. Міністерство охорони здоров'я України (2019) Проект постанови Кабінету Міністрів України «Про внесення змін до Технічного регламенту законодавчо регульованих засобів вимірювальної техніки» (moz.gov.ua/article/public-discussions-archive/proektpostanovi-kabinetu-ministriv-ukraini-pro-vnesennja-zmin-do-tehnichnogo-reglamentuzakonodavcho-regulovanih-zasobiv-vimirjuvalnoi-tehniki\#3).

\section{Відомості про авторів:}

Сергієнко Римма Петрівна — кандидат технічних наук, інженер з метрології, науково-виробничий відділ прикладної метрології тепло-технічних вимірювань, державне підприємство «Харківський регіональний науково-виробничий центр стандартизації, метрології та сертифікації» (ДП «Харківстандартметрологія»), Харків, Україна.

Жарко Юрій Григорович — кандидат технічних наук, провідний інженер із стандартизації, відділ оцінки відповідності продукції машинобудування, державне підприємство «Харківський регіональний науково-виробничий центр стандартизації, метрології та сертифікації» (ДП «Харківстандартметрологія»), Харків, Україна.

Тріщ Роман Михайлович — доктор технічних наук, професор, завідувач кафедри охорони праці, стандартизації та сертифікації, Українська інженерно-педагогічна академія, Харків, Україна. Адреса для кореспонденції:

Сергієнко Римма Петрівна

61002, Харків, вул. Мироносицька, 36

E-mail: rimmasergienk0474@gmail.com
17. uni-cert.ua/wp-content/uploads/2021/05/protsedura_ov 753-ua.pdf

18. Міністерство охорони здоров'я України (2017) Наказ Міністерства охорони здоров'я України від 11.10.2017 р. № 1245 (у редакції наказу Міністерства охорони здоров'я України від 20.01.2020 р. № 117) «Про затвердження переліку національних стандартів, відповідність яким надає презумпцію відповідності медичних виробів вимогам Технічного регламенту щодо медичних виробів» (moz.gov.ua/nakazi-moz?from=\&to=\&la bel $=\%$ E2\% $\% 4 \% 96+1245+)$.

19. КМУ (2004) Постанова КМУ від 09.11.2004р. № 1497 «Про затвердження Порядку державної реєстрації медичної техніки та виробів медичного призначення») (zakon.rada. gov.ua/laws/show/1497-2004-\%D0\%BF\#Text).

20. www.dls.gov.ua/wp-content/uploads/2018/07/\%D0\%A0\%D0\%B5\%D0\%B5\%D0\%B5\%D1 \%81\%D1\%82\%D1\%80.pdf

21. КМУ (2020) Постанова КМУ від 20.03.2020 р. № 224 «Про затвердження переліку товарів (у тому числі лікарських засобів, медичних виробів та/або медичного обладнання), необхідних для виконання заходів, спрямованих на запобігання виникненню і поширенню, локалізацію та ліквідацію спалахів, епідемій та пандемій гострої респіраторної хвороби COVID-19, спричиненої коронавірусом SARS-CoV-2, операції з ввезення яких на митну територію України та/або операції з постачання яких на митній території України звільняються від оподаткування податком на додану вартість» (zakon.rada.gov. ua/laws/show/224-2020-\%D0\%BF\#n9).

\section{Features of technical regulation concerning medical infrared thermometers}

\section{R.P. Sergiienko', Yu.H. Zharko', R.M. Trishch'}

${ }^{1} \mathrm{SE}$ «Kharkiv regional research and production center for standardization, metrology and certification», Kharkiv, Ukraine ${ }^{2}$ Ukrainian Engineering and Pedagogical Academy, Kharkiv, Ukraine

Abstract. The analysis of the development and current state of state technical regulation concerning medical infrared thermometers, the widespread use of which is currently due to the COVID-19 pandemic, is carried out. The stages of development of technical regulation are conditionally attributed to certain time periods - until 2016 (stage 1), from 2016 to 2020 (stage 2) and from 2020 to the present (stage 3). The problematic aspects of testing according to conformity assessment procedures in terms of the requirements for the metrological characteristics of medical devices with a measurement function as well as the features of the terminological specification of the types of medical thermometers in the relevant regulatory and legal documents at each stage of development are highlighted. The state of the normative base and the corresponding information resources are considered from the point of view of their completeness and availability for consumers. The issue of periodic metrological control of medical infrared thermometers, which during a pandemic can be provided on the Ukrainian market according to procedures alternative to the requirements of the Technical Regulations for medical devices, is raised.

Key words: medical products, medical infrared thermometers, tests, technical regulations, legally regulated measuring instruments, conformity assessment.

\section{Information about the authors:}

Sergiienko Rymma P. - Candidate of Technical Sciences, metrology engineer, Research and production department of applied metrology of heat engineering measurements, SE «Kharkiv regional research and production center for standardization, metrology and certification» (SE «Kharkovstandartmetrology»), Kharkiv, Ukraine.

Zharko Yurii H. — Candidate of Technical Sciences, Leading standardization engineer, Department of conformity assessment of engineering products, SE «Kharkiv regional research and production center for standardization, metrology and certification» (SE «Kharkovstandartmetrology»), Kharkiv, Ukraine.

Trishch Roman M. - Doctor of Technical Sciences, Professor, Head of the Department of labor safety, standardization and certification, Ukrainian Engineering and Pedagogical Academy, Kharkiv, Ukraine.

\section{Address for correspondence:}

Rymma Sergiienko

61002, Kharkiv, Mironositskaya str., 36

E-mail: rimmasergienk0474@gmail.com 